\title{
What factors attract and motivate dairy farm employees in their daily work?
}

\author{
Christina Lunner Kolstrup* \\ Department of Work Science, Business Economics and Environmental Psychology, Swedish University of \\ Agricultural Sciences, P.O. Box 88, SE-230 53 Alnarp, Sweden
}

\begin{abstract}
This study examined attraction and motivation factors important for people choosing to work and remain in the profession of dairy farm worker. The study comprised 194 agricultural students, 197 employed dairy farm workers and 147 employers. The study was based on questionnaires in which the key questions were: What would attract you to choose dairy farming as a profession? What attracts and motivates you in your daily work? What would motivate you to remain employed in dairy farming? Furthermore, in order to elucidate the farm employer's view, they were asked what they believed were important factors to attract and motivate young people to the profession. In general, the students, employees and employers had similar opinions on factors that attract and motivate dairy farm workers in their daily work. Although the order of priorities was different, they agreed that having fun at work, good leadership, feeling pride in their work, job security, good team spirit, living in the countryside, meaningful and interesting work, safe and healthy workplace, flexible work tasks, the farm having a good reputation and feedback from supervisors were among the most important attraction and motivation factors.
\end{abstract}

Keywords: Motivation, attraction, attitudes, farm workers, agriculture, questionnaire

\section{Introduction}

In Swedish agriculture there is a lack of manpower and in the future the sector will continue to need qualified workers. It is essential to know what attracts and motivates people to choose, work and remain in the profession if Swedish dairy farming is to be promoted as an attractive occupation.

There are a number of interesting theories within motivation psychology regarding what drives people to work [1-4]. The theories differ, but generally they concern the fulfilment of various needs in order to achieve mental wellbeing and satisfaction in relation to work.

During the period 1924-1932, human relation theory was developed at the Western Electric factories in the United States through the famous Hawthorne studies [5]. The results showed that the human need for recognition, security and the feeling of belonging to a group were more important for working morale and productivity than the material conditions.
In 1943 the psychologist Abraham Maslow [1] introduced his theory of the hierarchy of needs, which states that human needs follow a hierarchical structure. First, basic physiological needs (such as food, water and sleep) must be met, followed by safety (security of employment, family, property and health) and social contact (family, friendship and intimacy), and finally esteem (confidence, achievement, respect for and by others) and self-actualisation (the final level of psychological development that can be achieved when all basic and mental needs are fulfilled).

Hertzberg (1966) [3] concluded that in order to achieve acceptable job satisfaction, certain hygiene factors had to be fulfilled (e.g. tangible benefits, working conditions, physical work environment and personnel policies). However, motivation factors (e.g. possibility for responsibility and development, leadership, collaboration and work design) were needed in order to achieve a motivational effect.

More recent theories in motivation psychology believe that motivation includes concepts such as inter-

\footnotetext{
*Corresponding author: Christina.kolstrup@slu.se

$1051-9815 / 12 / \$ 27.50$ @ 2012 - IOS Press and the authors. All rights reserved
} 
nal and external motivation. Internal motivation is characterised by doing/choosing something because it is interesting or fun, while external motivation is characterised by doing/choosing something because it leads to a certain form of 'reward' [6-8].

The overall aim of this study was to help demonstrate how to create more attractive and motivational work in agriculture, with the focus on dairy farming. More specifically, the study sought to identify the attraction and motivation factors ${ }^{(1)}$ that are important to employees (prospective and existing dairy farm workers) and employers (dairy farm owners) in choosing to work and remain in Swedish dairy farming. An additional aim was to investigate the similarity between the perceptions of agricultural students and dairy farm employees and employers.

(1) The key factors involved e.g. salary, job security, flexible work schedule, freedom of work, work colleagues, working with animals, career development, education/training, responsibilities and participation.

\section{Materials and Methods}

\subsection{Subjects}

The target groups for the study were students attending agricultural colleges, employees on dairy farms and dairy farm employers on the largest dairy farms in Sweden. A register of students was established by contacting all 19 agricultural colleges in Sweden. An address register of the 245 largest dairy farms in Sweden was obtained from Statistics Sweden. Since there was no address register of workers employed in the dairy industry, questionnaires were distributed to them by their employers.

\subsection{Data collection}

The study took the form of a postal questionnaire and included questions concerning:

- Demographics (gender, age, education, professional experience and childhood environment),

- A list of 53 different attraction and motivation factors, which the participants were asked to evaluate in terms of importance (Table 1).

The questionnaire and two reminders were mailed to 281 agricultural students, 519 dairy farm employees and 245 dairy farm employers during December 2008 to May 2009. The study finally comprised 194 students (response rate 63\%), 197 employees (response rate 28\%) and 147 employers (response rate $39 \%)$.

\section{Results}

A demographic description of the participants and of the attraction and motivation factors that students, employees and employers believed were important in choosing and remaining in the profession is given below. The results are presented at the group level (students, employees and employers) and, where possible and relevant, by gender.

\subsection{Demographic description of the participants}

The student group consisted of 117 males (60\%) and 77 females $(40 \%)$, with an average age of 19 years. All the students were attending a course in animal husbandry at an agricultural college. The majority of students $(88 \%)$ had previous professional experience as a livestock worker. A major proportion of the students had been brought up in the countryside or on a farm $(81 \%)$.

The group of employees included 99 males $(50 \%)$ and 98 females $(50 \%)$. The average age of the employees was 35 years and they had on average 11.4 years of work experience. Like the students, the majority of the employees had been brought up in the countryside $(69 \%)$ and more than half had attended an agricultural college (63\%). The majority of employees $(86 \%)$ had permanent employment and worked on average 38.6 hours per week in herds with a mean size of 153 dairy cows. One-third of the employees had a managerial position.

The employers consisted of 119 males $(82 \%)$ and 27 females $(18 \%)$, with a mean age of 50 years. The farms were organised as private limited companies $(56 \%)$ or sole proprietorship $(38 \%)$. The companies had an average of 2.6 full-time employees and 2.0 part-time employees, and a mean herd size of 147 dairy cows. One-fifth of employers had nine years of school $(19 \%)$ or agricultural college $(31 \%)$ as the highest level of education.

\subsection{The most important and the least important attraction and motivation factors}

The participants in the study were asked to score the attraction and motivation factors on a scale of 1 to 4 , where 1 represented not important and 4 represented very important. The questions asked of each group were designed so that comparisons between the groups were possible. Table 1 shows the participants' prioritisation of the factors, reported as the 
mean and standard deviation (SD) of the participants' ranking for each factor.

The three groups studied had similar opinions on what attracts and motivates a dairy farm worker in his/her daily work (Table 1). The students, employees and employers all rated having fun at work, good leadership, pride in the profession, job security, good team spirit, living in the countryside, meaningful and interesting work tasks, a safe and healthy workplace, varied work tasks, the farm having a good reputation as a workplace and feedback from supervisors among the most important attraction and motivation factors. In addition, they all indicated that factors least important in attracting and motivating dairy farm workers in their work included weekend work, regular working hours, working from $8 \mathrm{am}$ to $4 \mathrm{pm}$, four weeks of continuous holiday, organic farming, opportunities for hunting and fishing and having a horse on the farm. It is worth mentioning that $80 \%$ of employees felt that their priorities were consistent with their current work situation.

\subsection{Different opinions between the three groups}

Even though the three groups had similar opinions about important attraction and motivation factors, there were differences in their priorities. These differences were primarily between students and employers (Table 1).

The employers gave higher priority to a fixed work schedule $\left(14^{\text {th }}\right.$ place $)$ than students $\left(38^{\text {th }}\right.$ place $)$ and employees $\left(33^{\text {rd }}\right.$ place). The employers also gave higher priority than students to the factors: milking cows, independence at work, creativity, provision of free working clothes, visits to other farms/companies, working with animals and working with the latest technology/machines. In contrast, the students prioritised career opportunities, access to occupational health services and opportunities for personal development at work higher than employers. Common to both students and employees was that they prioritised having their children grow up in the countryside $\left(12^{\text {th }}\right.$ and $21^{\text {th }}$ place, respectively), while this factor was valued significantly lower by the employers $\left(35^{\text {th }}\right.$ place). Students and employees also gave higher priority to having a good pension plan, living in the countryside and having a physically active job than employers.

There were differences between students and employees as well. The students valued an exciting business idea, regular communication, social activities at work, personal development at work and ca- reer opportunities higher than the employees. However, the employees gave higher priority to the factors: independence at work, provision of free working clothes and working with animals than the students.

\subsection{Different opinions between males and females}

In general, the male and female students, employees and employers had fairly consistent opinions on the attraction and motivation factors relevant to dairy farm workers in their daily work. However, there were differences of opinions. It was more important for male than female students to have their children growing up in the countryside $\left(9^{\text {th }}\right.$ place among males and $19^{\text {th }}$ among females) and to have social activities with colleagues at the workplace $\left(13^{\text {th }}\right.$ place among males and $33^{\text {rd }}$ among females). However, it was more important for female students to work with animals $\left(3^{\text {rd }}\right.$ place among females and $28^{\text {th }}$ among males) and to be able to attend further work-related education or training course $\left(25^{\text {th }}\right.$ place among females and $40^{\text {th }}$ among males).

Among the group of employed dairy farm workers, the most pronounced contrasts between the genders were male employees prioritising visits to other farms/companies higher than female employees $\left(24^{\text {th }}\right.$ place among males and $36^{\text {th }}$ among females). Furthermore, the female employees prioritised personal development higher than the male employees $\left(15^{\text {th }}\right.$ place among females and $26^{\text {th }}$ place among males).

The male employers believed that having working colleagues $\left(12^{\text {th }}\right.$ place), work responsibility $\left(16^{\text {th }}\right.$ place) and working with the latest technology/machines $\left(28^{\text {th }}\right.$ place $)$ were important for attracting and motivating dairy farm workers in their daily work. However, the female employers had different views $\left(22^{\text {th }}, 26^{\text {th }}\right.$ and $39^{\text {th }}$ place, respectively).

Furthermore, the female employers believed that the following factors were of greater importance for a dairy farm worker than their male counterparts: Written description of work procedures (10th place among females and 23rd among males), living in the countryside (12th place among females and 26th among males) and milking cows (18th place among females and 32nd among males).

\section{Discussion and Conclusions}

The study was conducted during the period 20082009 among 194 students attending agricultural col- 
lege, 197 employed dairy farm workers and 147 dairy farm employers in Sweden. The study thus comprised participants who were already related to the industry, which probably reflected their choice of attraction and motivation factors. The response rate for students was satisfactory $(63 \%)$, but less good for employers (39\%) and employees (28\%). The reason for the low response rate among employers could be poorer quality of address register than expected. An analysis of the non-respondent employers showed that they had ceased milk production, no longer had employees or for various reasons did not wish to participate in the study.

Every year Statistics Sweden gathers farm-specific information which also includes the approximate number of employees on the farm. Since there are no available address registers for employed farm workers, we distributed the questionnaires through the employers based on these approximations. This may have contributed to more questionnaires being sent out than there were in fact employees and thus we received a low response rate among dairy farm employees. The gender distribution between the different groups was approximately $50 \%$ with the exception of female employers, who represented only $18 \%$. The results of the study are considered reliable for the three study groups. However, the generalisation may be weaker because of the less satisfactory response rate among employees and employers.

A number of previous studies have been conducted in motivation psychology, but mainly among students and schoolchildren in relation to learning. Far fewer studies have been carried out among the workforce. In Sweden, these studies on work motivation among employees have mainly included the car manufacturing and healthcare sectors [9-12]. Some studies have been conducted in the agricultural sector in relation to motivation and commitment [13-17]. However, none has taken a holistic approach and studied the attraction and motivation factors for both upcoming and current employed agricultural workers and for employers.
In this study the students, employees and employers had quite similar conceptions of what workrelated factors attract and motivate a dairy farm worker in his/her daily work: the work should be fun with interesting, meaningful and varied work tasks. They wanted to feel pride in their work, be able to live in the countryside and have working colleagues. This is consistent with other studies on farmers and farm workers [13-17]. Furthermore, they believed that a good leader who provides feedback was important, confirmed findings in a study by Kolstrup et al. (2008) [18]. In addition, it was important that the farm had a safe and healthy work environment and a good reputation as a workplace. All three groups also believed that it was less important that dairy farm work involved weekend work, irregular working hours and overtime. In terms of motivation psychology theory, the students and employees had fulfilled their primary needs according to the hierarchy of needs [1] and hygiene factors [3]. In general, high salary is considered to be a significant attraction and motivation factor, but the three groups did not rank this factor as very important. This, together with the other factors valued as important by the study groups, indicates that prospective and existing dairy farm workers are primarily driven by internal motivators [6-8], i.e. they choose their profession and work as employees in dairy farming because it is interesting and fun. They are not driven by external motivators [6-8], i.e. choosing dairy farming because it leads to a certain form of 'reward'.

There were differences in priorities between the three groups and especially between students and employers. It is important for employers to note these differences, as students are prospective employees. According to this study, they had somewhat different expectations and requirements than employed workers. Swedish dairy farming should promote itself better as a workplace. Raising its profile in society and emphasising the importance of agriculture would probably raise the status of the profession. 
Table 1

Prioritisation by agricultural students, dairy farm employees and employers of the attraction and motivation factors important for choosing to work and remain in the profession of dairy farm worker.

\begin{tabular}{|c|c|c|c|c|c|c|}
\hline \multirow[b]{2}{*}{ Attraction and motivation factors } & \multicolumn{2}{|c|}{ Students $(N=194)$} & \multicolumn{2}{|c|}{ Employees $(N=197)$} & \multicolumn{2}{|c|}{ Employers $(N=147)$} \\
\hline & Place $^{*}$ & Mean (SD) & Place $^{*}$ & Mean (SD) & Place $^{*}$ & Mean (SD) \\
\hline Bonus payment & 40 & $2.43(0.73)$ & 43 & $2.16(0.81)$ & 46 & $2.01(0.74)$ \\
\hline Career opportunities & 27 & $2.81(0.76)$ & 42 & $2.23(0.78)$ & 41 & $2.24(0.70)$ \\
\hline Children growing up in the countryside & 12 & $3.19(0.87)$ & 21 & $3.05(0.96)$ & 35 & $2.58(0.87)$ \\
\hline Clear goals and visions & 15 & $3.12(0.62)$ & 14 & $3.16(0.78)$ & 24 & $2.95(0.67)$ \\
\hline Creativity & 29 & $2.79(0.76)$ & 20 & $3.09(0.69)$ & 16 & $3.01(0.66)$ \\
\hline Education/training (work-related) & 34 & $2.60(0.82)$ & 30 & $2.78(0.81)$ & 27 & $2.68(0.71)$ \\
\hline Environmental conscious company & 30 & $2.78(0.78)$ & 29 & $2.79(0.81)$ & 34 & $2.59(0.79)$ \\
\hline Exciting business idea & 24 & $2.89(0.74)$ & 34 & $2.67(0.82)$ & 31 & $2.62(0.81)$ \\
\hline Feedback from supervisors & 13 & $3.14(0.71)$ & 10 & $3.35(0.65)$ & 8 & $3.36(0.62)$ \\
\hline Fixed work schedule & 38 & $2.51(0.85)$ & 33 & $2.71(0.90)$ & 14 & $3.04(0.72)$ \\
\hline Flexible work hours & 35 & $2.59(0.77)$ & 35 & $2.63(0.84)$ & 36 & $2.53(0.72)$ \\
\hline Four weeks of continuous holiday & 46 & $2.22(0.94)$ & 44 & $2.09(1.01)$ & 44 & $2.09(0.75)$ \\
\hline Fun at work & 1 & $3.76(0.44)$ & 1 & $3.61(0.58)$ & 1 & $3.57(0.52)$ \\
\hline Good staff and locker rooms & 19 & $3.08(0.75)$ & 15 & $3.14(0.75)$ & 15 & $3.03(0.61)$ \\
\hline Good leadership & 2 & $3.71(0.49)$ & 2 & $3.61(0.64)$ & 5 & $3.43(0.65)$ \\
\hline Good team spirit & 5 & $3.42(0.64)$ & 6 & $3.50(0.60)$ & 3 & $3.51(0.58)$ \\
\hline High salary & 23 & $2.94(0.54)$ & 25 & $2.91(0.63)$ & 25 & $2.93(0.48)$ \\
\hline House on the farm & 39 & $2.47(0.73)$ & 45 & $2.03(0.99)$ & 43 & $2.13(0.94)$ \\
\hline Independence at work & 36 & $2.55(0.78)$ & 17 & $3.13(0.71)$ & 23 & $2.96(0.69)$ \\
\hline Influence and participation & 17 & $3.09(0.59)$ & 13 & $3.19(0.72)$ & 12 & $3.15(0.64)$ \\
\hline Job security & 4 & $3.47(0.65)$ & 5 & $3.50(0.61)$ & 2 & $3.56(0.56)$ \\
\hline Living in the countryside & 6 & $3.40(0.80)$ & 9 & $3.40(0.82)$ & 21 & $2.97(0.87)$ \\
\hline Managerial position & 32 & $2.68(0.75)$ & 41 & $2.29(0.83)$ & 39 & $2.28(0.69)$ \\
\hline Meaningful and interesting work & 7 & $3.30(0.69)$ & 8 & $3.41(0.62)$ & 9 & $3.35(0.55)$ \\
\hline Milking cows & 44 & $2.28(0.92)$ & 36 & $2.63(0.95)$ & 29 & $2.66(0.89)$ \\
\hline Occupational health services & 26 & $2.83(0.71)$ & 31 & $2.74(0.89)$ & 38 & $2.40(0.76)$ \\
\hline Organic production & 51 & $1.72(0.81)$ & 48 & $1.78(0.93)$ & 53 & $1.56(0.83)$ \\
\hline Horse on the farm & 52 & $1.64(0.83)$ & 53 & $1.56(0.80)$ & 50 & $1.70(0.70)$ \\
\hline Paid physical exercise & 41 & $2.41(0.82)$ & 39 & $2.46(0.98)$ & 45 & $2.08(0.68)$ \\
\hline Provision of free telephone and car & 42 & $2.31(0.87)$ & 46 & $1.87(0.81)$ & 47 & $1.90(0.71)$ \\
\hline Provision of free working clothes & 31 & $2.77(0.86)$ & 16 & $3.14(0.84)$ & 19 & $2.99(0.66)$ \\
\hline Performance review & 45 & $2.24(0.77)$ & 38 & $2.49(0.84)$ & 37 & $2.51(0.78)$ \\
\hline Personal development & 9 & $3.27(0.61)$ & 23 & $3.02(0.70)$ & 20 & $2.97(0.62)$ \\
\hline Physical active work & 20 & $3.05(0.65)$ & 22 & $3.03(0.70)$ & 32 & $2.61(0.63)$ \\
\hline Possibilities for hunting and fishing & 47 & $2.05(0.94)$ & 51 & $1.65(0.88)$ & 49 & $1.75(0.71)$ \\
\hline Pride in the profession & 3 & $3.54(0.63)$ & 4 & $3.50(0.65)$ & 4 & $3.44(0.60)$ \\
\hline Regular communication & 14 & $3.14(0.71)$ & 24 & $2.97(0.83)$ & 22 & $2.97(0.68)$ \\
\hline Regular planning meetings & 33 & $2.67(0.75)$ & 32 & $2.73(0.85)$ & 28 & $2.68(0.77)$ \\
\hline Regular work hours & 48 & $1.84(0.89)$ & 47 & $1.79(0.94)$ & 48 & $1.89(0.79)$ \\
\hline Pension plan & 25 & $2.87(0.78)$ & 27 & $2.81(0.82)$ & 40 & $2.28(0.80)$ \\
\hline Safe \& healthy work place & 8 & $3.28(0.73)$ & 11 & $3.30(0.66)$ & 10 & $3.33(0.57)$ \\
\hline Social activities at work & 21 & $2.98(0.77)$ & 37 & $2.60(0.81)$ & 30 & $2.62(0.79)$ \\
\hline Varied work tasks & 10 & $3.26(0.69)$ & 7 & $3.49(0.62)$ & 11 & $3.23(0.57)$ \\
\hline Weekend work & 53 & $1.63(0.75)$ & 50 & $1.67(0.83)$ & 51 & $1.65(0.74)$ \\
\hline Work responsibility & 28 & $2.81(0.77)$ & 19 & $3.11(0.77)$ & 18 & $3.00(0.68)$ \\
\hline Visits to other farms/companies & 37 & $2.55(0.75)$ & 28 & $2.08(0.86)$ & 26 & $2.86(0.64)$ \\
\hline Work between 8 am to $4 \mathrm{pm}$ & 49 & $1.77(0.81)$ & 52 & $1.61(0.83)$ & 52 & $1.63(0.64)$ \\
\hline Work place has a good reputation & 11 & $3.26(0.73)$ & 12 & $3.21(0.81)$ & 7 & $3.39(0.63)$ \\
\hline Working colleagues & 18 & $3.08(0.77)$ & 18 & $3.12(0.82)$ & 13 & $3.13(0.74)$ \\
\hline Working overtime & 50 & $1.73(0.78)$ & 49 & $1.73(0.73)$ & 42 & $2.14(0.76)$ \\
\hline Working with animals & 16 & $3.10(0.82)$ & 3 & $3.55(0.65)$ & 6 & $3.39(0.63)$ \\
\hline Working with the latest technique/machines & 43 & $2.31(0.79)$ & 40 & $2.36(0.87)$ & 33 & $2.60(0.76)$ \\
\hline Written description of work procedures & 22 & $2.94(0.73)$ & 26 & $2.87(0.80)$ & 17 & $3.00(0.69)$ \\
\hline
\end{tabular}




\section{References}

[1] A. Maslow. A theory of human motivation. Psychological Review, 50 (1943), 370-396.

[2] V. H. Vroom. Work and Motivation. Wiley, New York: 1964, pp 1-397.

[3] F. Hertzberg. Work and the human nature. Thomas Y Cromwell Co, New York, 1966.

[4] C.P. Alderfer. Existence, Relatedness, and Growth: Human Needs in Organizational Settings. Free Press, New York, 1972.

[5] S.J. Harris O.J \& Hartman. Human Behaviour at Work - With an Emphasis on Ethics. In: Human Behaviour at Work. West Publishing, New York, Chapter 6-9, 1992, pp 111-242.

[6] R. M. Ryan \& E. L. Deci. Intrinsic and Extrinsic Motivations: Classic Definitions and New Directions. Contemporary Educational Psychology, 2 (2000), 54-67.

[7] K. W. Thomas. Intrinsic Motivation and How it Works - Are you energized by your job or just spinning your wheels? There's a way to tell. In: Training, 2000, pp 130-135.

[8] J.S. Eccles \& A. Wigfield. Motivational Beliefs, Values and Goals. Annual Review of Psychology 53 (2002), 109-132.

[9] J-E. Rendahl. Arbetets drivkrafter: existentiellt värde och auktoritetsorientering: två dimensioner som belyser arbetets mening för de anställda i kriminalvården. Work incentives: existential value and authority orientation: two dimensions that illustrate the work meaningful for employees in correctional treatment. Dissertation. Lunds University, 1992. (In Swedish with an English Summary)

[10] M. Maccoby. Why work? Motivating the new workforce. Miles River Press, 1995, pp 1-296.

[11] M. Åteg, A. Hedlund \& B. Pontén. Attraktivt arbete. Från anställdas uttalanden till skapandet av en modell.
Attractive work. From the employees' statements to the making of a model. Working life in transition 2004: (2004), National Institute for working life. Stockholm. (In Swedish with an English Summary).

[12] A. Wikman. About work engagement and other motives for working than economic. Om arbetsengagemang och andra motiv för arbetet än ekonomiska. Working life in transition 2005:4 (2005). National Institute for working life, Stockholm. (In Swedish).

[13] Nitsch, U. 1982. How do farmers view work and information? Hur ser jordbrukarna på sitt arbete och på information? Report 196. Swedish University of Agricultural Sciences. Uppsala. (In Swedish).

[14] C. Erdtman and J. Strömberg. Hur skall arbetsgivaren rekrytera, utveckla och behålla personal i svinproduktionen? How should employers recruit, develop and retain staff in swine production? Company Project ordered by the agricultural center for swine advisors, Maxima. Swedish University of Agricultural Sciences, Skara, 2002. (In Swedish).

[15] M. Nygren. The route of choice - a study on youth elections to high school. Vägvalet - En undersökning om ungdomars val till gymnasiet. Confederation of Swedish Enterprise, Stockholm, 2003. (In Swedish)

[16] S. Eriksson. Natural resources - what, why and what? A questionnaire study on agricultural students. Naturbruk - Vilka, varför och sen då? En enkätstudie om naturbrukselever. The Swedish Vocational Board of Agriculture and Gardening, Stockholm, 2003. (In Swedish)

[17] M. Törnquist. Attractive workplaces on Swedish dairy farms: how can employers create work satisfaction? Attraktiva arbetsplatser i svensk mjölkproduktion: hur får man de anställda att trivas. Master's Thesis 358, Swedish University of Agricultural Sciences, Uppsala, 2004. (In Swedish with an English Summary)

[18] C. Kolstrup, P. Lundqvist and S. Pinzke. Psychosocial work environment among employed Swedish dairy and pig farmworkers. Journal of Agromedicine, 13:1 (2008), $23-36$. 